\title{
The Effects of Chimeric Cells following Donor Bone Marrow Infusions as Detected by PCR-flow Assays in Kidney Transplant Recipients
}

\author{
Rolando Garcia-Morales, ${ }^{*}$ Manuel Carreno, ${ }^{*}$ James Mathew, ${ }^{*}$ Keith Zucker, ${ }^{*}$ Robert Cirocco, ${ }^{*}$ Gaetano Ciancio, ${ }^{*}$ \\ George Burke, ${ }^{\star}$ David Roth, ${ }^{\ddagger}$ Donald Temple, ${ }^{\star}$ Anne Rosen, ${ }^{*}$ Laphalle Fuller, ${ }^{\S}$ Violet Esquenazi, ${ }^{\star} \S$ Theodore Karatzas, ${ }^{\star}$

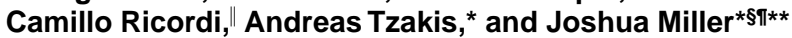 \\ ${ }^{*}$ Department of Surgery, Division of Transplantation, ${ }^{\ddagger}$ Department of Medicine, ${ }^{\S}$ Department of Microbiology/Immunology, ${ }^{\| C e l l}$ \\ Transplant Center, Diabetes Research Institute, and ${ }^{\top}$ Department of Pathology, University of Miami School of Medicine, Miami, Florida \\ 33101; and **The Miami Veterans Administration Medical Center, Miami, Florida 33101
}

\begin{abstract}
40 recipients of first cadaver kidney transplants were given perioperative donor vertebral bone marrow infusions (DBMC), compared with 100 controls who did not receive donor bone marrow. The immunosuppressive regimen included OKT3, Tacrolimus, and steroid maintenance therapy, and, in some patients, newly introduced mycophenolate mofetil. This report describes the 24-mo actuarial follow-up and several immunological monitoring studies including sequential measurements of donor bone marrow lineage subset chimerism by the recently reported PCR-flow assay. This is a sensitive in situ PCR detection system for donor versus recipient histocompatibility genes as well as cell surface CD epitope markers using flow cytometry. The results indicate $(a)$ the stabilization of the donor $\mathrm{CD} 3+$ and $\mathrm{CD} 34+$ cells in recipient peripheral blood at levels below $1 \%$ between 6 mo and 1 yr postoperatively, with a $\mathbf{1 0}$-fold higher level of donor cell chimerism of these lineages in recipient iliac crest marrow; (b) significantly lower levels of chimerism in peripheral blood up to 6 mo postoperatively in patients who had early acute (reversible) rejection episodes compared with those who did not; $(c)$ a higher degree of chimerism seen in patients who were class II MHC HLA DR identical with their donors; $(d)$ the identification of a high proportion of the donor bone marrow derived CD3 dimly staining subset of T cells (to which regulatory functions have been ascribed) in recipient peripheral blood and especially in recipient bone marrow; and (e) an unexpectedly increased susceptibility to clinically significant infections (primarily viral), and even death in the DBMC-infused group, compared with controls, but no graft losses because of rejection in the DBMC-infused group. Mixed lymphocyte culture assays showed a trend toward a greater number of nonspecifically low reactors in the DBMC group, as well as a greater number of nonspecifically high reactors in the controls $(P=0.058)$. The autologous mixed lymphocyte reaction also indicated a trend towards nonspecific immune activation in the DBMC group. Finally, anti-cytomegaloviral IgG antibody reactivity was significantly inhibited in the DBMC group 4-6 mo postopera-
\end{abstract}

Address correspondence to Joshua Miller, M.D., Department of Surgery, Division of Transplantation, University of Miami School of Medicine, P.O. Box 012440 (R-440), Miami, FL 33101. Phone: 305243-6171; FAX: 305-243-6516.

Received for publication 30 September 1996 and accepted in revised form 4 December 1996.

The Journal of Clinical Investigation

Volume 99, Number 5, March 1997, 1118-1129 tively $(P=<0.05)$. In the controls, there were no donor cell lineages detected by PCR-flow in the peripheral blood. These rather unexpected findings, indicating a more depressed cellular and humoral immune capacity in the DBMC cadaver kidney transplant recipients in this relatively early follow-up period, are discussed relevant to chimerism, MHC restriction, and suppressor activity brought about by specialized DBMC subsets, which still need to be defined. (J. Clin. Invest. 1997. 99:1118-1129.) Key words: tolerance $\cdot$ rejection $\bullet$ immunosuppression $\cdot T$ cells $\bullet$ stem cells

\section{Introduction}

Clinical trials are underway in several institutions to determine whether infusions of donor bone marrow cells (DBMC) ${ }^{1}$ can enhance organ allograft survival (1-3). We have previously reported preliminary results in first cadaver kidney transplant recipients that were given large doses $\left(5 \times 10^{8}\right.$ cells $/ \mathrm{kg}$ body weight) of vertebral body bone marrow from the specific cadaver donor in one or two infusions in the peritransplant period, compared to controls receiving identical immunosuppressive protocols, but without bone marrow infusions (4). We described a novel assay designated as the PCR-flow to detect and quantitate macro- and microchimerism of DBMC in these recipients (4). This flow cytometry assay has combined the advantages of the sensitivity of PCR to detect and count cells with a single MHC gene copy difference between donor and recipient (using DR $\beta 1$ fluoresceinated primers), together with the ability to cytologically characterize these cells by CD epitope monoclonal antibodies, in samples of peripheral blood (or other sites, such as bone marrow). The initial results that were described in 20 of 28 recipients of the DBMC infusions able to be followed by PCR-flow (DR $\beta 1$ mismatched) had indicated that until 14 mo posttransplant, there was a gradual but persistent decline in donor bone marrow lineage cells in the peripheral blood (4). However, in recipient iliac crest bone marrow aspirates studied between 23 and 57 wk postoperatively, there was approximately one order-of-magnitude higher mean level of donor CD34+ subsets than were seen in recipient peripheral blood. In general, after DBMC infusions, the percentage of the CD34+ cell subset expressing the donor DR $\beta 1$ genes was surprisingly high, supporting the notion that engraftment of cells of donor bone marrow lineage occurred in the recipient marrow (and peripheral blood).

1. Abbreviations used in this paper: $\mathrm{CMV}$, cytomegalovirus; DBMC, donor vertebral bone marrow infusions; MESF, molecules of equivalent soluble fluorochrome; MLC, allogeneic mixed lymphocyte culture; NT, non-T lymphocytes; T, E rosette forming cells. 
In this report, these findings are extended in follow-up studies of chimerism and its clinical correlation in 40 first cadaver kidney transplant recipients infused with DBMC, now between 3 and 24 mo postoperatively compared with 100 controls transplanted during the same time period with similar immunosuppressive protocols, but not given DBMC (vide infra). 25 of the controls were serially studied for chimerism by PCRflow analysis. A key question was if there were immunologic and/or clinical effects of DBMC infusion that were detectable in this relatively early post-transplant period. Although no attempt was made to randomize these patients, and DBMC was given purely on the basis of its availability, several traditional risk variables defining patient and graft survival have been compared retrospectively between the two groups. Other new studies are described, such as $(a)$ the use of primers for certain class I gene disparities between donor and recipient (now available) in PCR-flow if class II MHC molecular or serological assays could detect no differences (i.e., donor-recipient class II MHC identity). Consequently, the question could now be asked whether class II MHC identity would be associated with an enhanced degree of chimerism, since there did not appear to be as much rejection in this group (4-6). (b) The identification and quantitation of an "intermediate" or "atypical" subset of $\mathrm{T}$ cells expressing significantly lower concentrations of CD3 molecules, the "CD3 dim" population, apparently uniquely of bone marrow lineage (characterized in other studies as also being TCR $\alpha \beta+\mathrm{CD} 4-, \mathrm{CD} 8-$ ). These were designated to be of donor or recipient origin by the PCR-flow assay. (c) Finally, it was questioned whether a correlation could be made between in vitro cellular, as well as humoral, immune responses, and an altered clinical course.

\section{Methods}

\section{Patients and immunosuppressive protocols}

All recipients of first cadaver kidney transplants between September 1, 1994 and June 30, 1996 were included in the study. Cadaver donor bone marrow was not randomly selected, because of its unpredictable availability. When the bone marrow was available, informed consent was given for infusion of cryopreserved aliquots rapidly thawed at the bedside $(4,7)$, in two planned intervals: $(a)$ between 1 and $4 \mathrm{~d}$ postoperatively, and $(b)$ between 10 and $14 \mathrm{~d}$ postoperatively. Although there was about a $50 \%$ quantitative loss from the fresh state, the bone marrow samples immediately before infusion were found to have a viability of not less than $75 \%$ using Trypan blue exclusion $(7,8)$. These two time intervals chosen for infusion coincided with the timing ( $a$ ) after the initiation, and $(b)$ after completion, respectively, of an induction course of OKT3 (Ortho-McNeil Pharmaceuticals, Raritan, NJ) mAb therapy (postoperative days 0-10). As maintenance therapy, tacrolimus (Prograf ${ }^{\mathrm{TM}}$; Fujisawa Pharmaceuticals, Tokyo, Japan) was instituted at a dosage of $0.1 \mathrm{mg} / \mathrm{kg}$ twice a d, when stable renal function had occurred (serum creatinine had decreased to $<4$ $\mathrm{mg} / \mathrm{dl}$ in the absence of dialysis); methyl prednisolone (Upjohn Pharmaceuticals, Kalamazoo, MI) was given in initially high doses with a subsequent weaning schedule towards maintenance therapy, so that at 1 and 3 mo postoperatively, target dosaging of 0.3 and $0.15 \mathrm{mg} / \mathrm{kg}$, respectively, were usually achieved. The remaining patients (controls, who did not receive bone marrow) also signed informed consents for hematologic studies to be sequentially performed. They were given identical immunosuppressive regimens. Mycophenolate mofetil (Cell$\mathrm{Cept}^{\mathrm{TM}}$; Roche Laboratories, Basel, Switzerland) was later added to the immunosuppressive regimen in equivalent numbers of recipients in both the DBMC-infused and control groups, in a planned schedule of $1 \mathrm{~g}$ twice daily. However, in some patients, because of gastrointestinal toxicity, dosage reduction by $50 \%$ was necessary.
Acute rejection was defined as a rise in baseline serum creatinine of $0.3 \mathrm{mg} / \mathrm{dl}$ or greater and was always accompanied by a kidney transplant biopsy, which confirmed the diagnosis. Anticytomegaloviral (CMV) prophylaxis with Gancyclovir ${ }^{\circledR}$ (Roche Laboratories, Palo Alto, CA) was routinely used during the OKT3 induction course, and prophylactic maintenance therapy with trimethaprim-sulfa was given to prevent pneumocystis and nocardia infections. No patient was lost to follow-up. Monitoring of peripheral blood for chimerism analysis was performed weekly for 1 mo postoperatively and then monthly thereafter. Iliac crest bone marrow aspirates were performed simultaneously with peripheral blood studies between 8 and 23 mo postoperatively.

\section{The PCR-flow assay for class I gene chimerism analysis}

The PCR-flow assay has been more fully described previously in reference 4. Briefly, peripheral blood mononuclear cells (PBMC) or bone marrow aspirates were fixed with buffered formalin and their membranes were solubilized with NP40. Fluoresceinated sequencespecific oligonucleotide primers were synthesized and the mixture of cells and primers placed in the thermocycler with appropriate PCR reagents under PCR conditions previously described. After amplification, anti-CD3 (PerCP) and anti-CD34 (PE) were added and flow cytometry was performed in an EPICS ELITE cytometer (Coulter Electronics, Hialeah, FL) using calibration parameters previously described for four color analysis (4). Also, new class I primers have now been utilized that have sequences specific for HLA-A1, -A2, and -A26 for three class II identically matched donor-recipient pairs who differed at these specificities. These primers were found to have no donor-recipient cross-reactivity in unmixed sample analyses. Their sequences, as described at the XII International Histocompatibility Workshop (Paris, June 1996), were as follows:

HLA-A1

5'GGA CCA GGA GAC ACG GAA TA

3'AGG TAT CTG CGG AGC CCG

HLA-A2

5'GGA CCA GGA GAC ACG GAA TA

3'GAG CCA CTC CAC GCA CGT

\section{HLA-A26 \\ 5'CGG AAT GTG AAG GCC CAC T \\ 3'CAA GAG CGC AGG TCC TCG.}

\section{Quantitation of CD3 molecules of equivalent soluble fluorochrome (MESF) on T cells by flow cytometry}

To distinguish between the CD3 dim and bright $\mathrm{T}$ cells in bone marrow and peripheral blood, we established two discrete regions in the appropriate quadrant of the flow cytometer histogram; one for the "CD3 dim" T cells that were CD4-CD8- and expressed at least $33 \%$ fewer CD3 epitopes per cell than the (mature) bright ones; the second, for the "CD3 bright" $\mathrm{T}$ cells that were either CD4+ or CD8+ cells and expressed the standard (high) concentration of CD3 epitopes, accounting for the majority of $\mathrm{T}$ cells within peripheral blood.

The assessment of MESF to determine the number of epitopes of CD3 per cell was accomplished with the Quantum 1000 fluorescence kit and the software program QuickCal (Flow Cytometry Standards, Inc., San Juan, Puerto Rico). In this program, a regression calibration plot was generated using a series of five reference standard beads (0-474,498 U). From the mean channel fluorescence number of the experimental samples on the regression plot, the mean of MESF units of fluorochrome was calculated for each specific population (9).

CD3 + dimly staining cells $(C D 3+$ dim cells) analyzed retrospectively by flow cytometry

In a retrospective analysis of stored PCR-flow data of cadaver kidney transplant recipients, peripheral blood samples were tested for levels of chimerism of $\mathrm{CD} 3+(\mathrm{PerCP})$ cells. A standardization was performed on samples from 13 control laboratory volunteers, so that pa- 
rameters to differentiate $\mathrm{CD} 3$ bright from $\mathrm{CD} 3$ dim cells could be set. The CD3 + dim cells were detected at 514 \pm 119 (SD) linear channels, while the $\mathrm{CD} 3+$ bright cells were detected at $817 \pm 14$ (SD) linear channels in an analysis performed in the EPICS ELITE flow cytometer using list mode to retrieve and re-run the samples.

\section{Lymphoproliferative assays}

Mixed lymphocyte culture $(M L C)$. The proliferative responses of the peripheral blood lymphocytes from renal transplant recipients were monitored using a standard $\left[{ }^{3} \mathrm{H}\right]$ thymidine incorporation assay (10) with few modifications. Briefly, $1 \times 10^{5} \mathrm{PBL}$ purified by ficoll-hypaque density gradients were stimulated with $1 \times 10^{5}$ irradiated $(3,000 \mathrm{R}) \mathrm{fi}$ coll-purified donor spleen cells, as well as PBL or spleen cells from an indifferent individual selected to be HLA DR disparate with donor and recipient (specificity control). A standard panel of indifferent cells selected to have varied DR specificities was also used as a control for specificity. The donor cells were cryopreserved and thawed at the time of culture preparation. Indifferent cells were similarly treated. Additional controls consisted of using these cells as responding cells at each time interval to be studied. The assays were carried out in triplicate in 96-well flat-bottom plates at a total volume of 0.2 $\mathrm{ml} /$ well culture medium (medium 199 supplemented with $15 \%$ normal AB serum, $2 \mathrm{mM}$ L-glutamine, $10 \mathrm{mM}$ Hepes, and $1 \times$ antibioticantimycotic solution (all from GIBCO BRL, Gaithersburg, MD) at $37^{\circ} \mathrm{C}$ in $5 \% \mathrm{CO}_{2}$. On day $7,1 \mu \mathrm{Ci}$ of $\left[\right.$ methyl $\left.-^{3} \mathrm{H}\right]$ thymidine was added to each well and, after $18 \mathrm{~h}$, the cultures were processed using a cell harvester (Skatron, Inc., Sterling, VA). The radioactive incorporation was measured using a Packard-Beta counter (Packard Instrs., Meriden, $\mathrm{CT}$ ), and stimulation indices (SI) were calculated using the formula

$$
\text { SI }=\frac{\begin{array}{c}
\text { CPM in experimental combinations } \\
\text { (self versus x-irradiated donor or indifferent cells) }
\end{array}}{\begin{array}{c}
\text { CPM in control combinations } \\
\text { (self versus x-irradiated self cells). }
\end{array}}
$$

Autologous mixed lymphocyte reaction ( $A M L R$ ). Peripheral blood mononuclear cells were collected from whole blood using ficollhypaque density gradients. The cell concentrations were adjusted to $5 \times 10^{6} / \mathrm{ml}$ in RPMI 1640 , supplemented with $20 \%$ FCS (GIBCO BRL). As we have previously described $(11,12)$, the cells were mixed with an equal volume of $1 \%$ sheep erythrocytes (E) that were treated with aminoethylthioronium bromide. The $\mathrm{E}$ rosette-forming cells $(\mathrm{T})$ were layered onto a chilled ficoll-hypaque gradient. After $2 \mathrm{~h}$ at $4^{\circ} \mathrm{C}$, the tubes were centrifuged $(600 \mathrm{~g})$. Non-T lymphocytes (NT) were obtained from the interface and the rosetted $\mathrm{T}$ lymphocytes in the pellet were treated with distilled water to lyse the erythrocytes. Both fractions, i.e., NT and T, were washed in media and then adjusted to a concentration of $1 \times 10^{6} / \mathrm{ml}$ in RPMI-1640, supplemented with L-glutamine, penicillin-streptomycin, and $7 \%$ filtered heat-inactivated pooled AB human serum (complete medium). Assays were performed in quadruplicate in microtiter plates using $1 \times 10^{5}$ responding T cells and $1 \times 10^{5} \mathrm{x}$-irradiated $(5,000 \mathrm{R})$ stimulating NT cells in a total volume of $0.2 \mathrm{ml}$ of complete medium. Cultures were incubated for $3,5,7$, and $9 \mathrm{~d}$ at $37^{\circ} \mathrm{C}$ in a humidified $7 \% \mathrm{CO}_{2}$ atmosphere and then pulsed with $1 \mu \mathrm{Ci}$ of $\left[\right.$ methyl $\left.{ }^{3} \mathrm{H}\right]$ thymidine and processed as described for the MLC assays.

\section{Estimation of IgG antibodies to CMV by ELISA}

A semiquantitative test for anti-CMV $\operatorname{IgG}$ antibodies in sera pretransplant and 4-6 mo posttransplant was utilized for both control and DBMC infused recipients. This consisted of an ELISA using the Clin-ELISA kit from Incstar Corp. (Stillwater, MN). The manufacturer's protocol was followed with two different dilutions for each unknown serum and the results were calculated as ELISA values using a reference serum.

\section{Statistical analysis}

In most of the studies, the Student's $t$ test as well as the Wilcoxon's Rank sum test were performed for the determination of statistical significance. Exceptions are detailed in each section.

\section{Results}

\section{Patient demographics}

Between 1 September 1994 and 30 June 1996, 140 first cadaver kidney transplants were performed. Of these, 40 received DBMC infusions. The remaining 100 were considered controls for retrospective analysis of patient and graft survival. The key risk factors are listed in Table I, comparing the two groups, i.e., age, race, original disease (diabetes), percent reactive antibodies, histocompatibility match, donor age, average cold ischemia time, and average warm ischemia time. Among these variables there were no notable differences between the two groups. In this center, a minimum acceptance criterion for first cadaver donor renal transplantation has been at least one class

\begin{tabular}{|c|c|c|c|}
\hline & Risk factors & DBMC infused $(n=40)$ & Control $(n=100)$ \\
\hline \multirow[t]{8}{*}{ (A) Demographics } & Mean recipient age in years (range) & $46.4(22-70)$ & $45.64(11-73)$ \\
\hline & African-american (\%) & $7 / 40(18 \%)$ & $20 / 100(20 \%)$ \\
\hline & Diabetes $(\%)$ & $8 / 40(20 \%)$ & $16 / 100(16 \%)$ \\
\hline & $\%$ Panel reactive antibodies (Mean \pm S.E. $)$ & $9.12 \pm 2.83 \%$ & $4.89 \pm 1.10 \%$ \\
\hline & Mean donor age \pm S.E. & $32.2 \pm 2.3$ & $31.6 \pm 1.7$ \\
\hline & Cold ischemia time in hours (Mean \pm S.D.) & $40.5 \pm 6.5$ & $37.6 \pm 8.3$ \\
\hline & Warm ischemia time in minutes (Mean \pm S.D.) & $55.7 \pm 14.3$ & $53.9 \pm 12.3$ \\
\hline & Match (Mean \pm S.E.) of a total of 6 HLA antigens & $1.89 \pm 0.13 *$ & $2.20 \pm 0.11 *$ \\
\hline \multirow[t]{7}{*}{ (B) Outcome } & Morbidity and mortality & & \\
\hline & Deaths & $4 / 40(10 \%)^{\ddagger}$ & $2 / 100(2 \%)^{\ddagger}$ \\
\hline & Acute rejections (total) & $7 / 40(17 \%)^{*}$ & $16 / 100(15.0 \%)^{*}$ \\
\hline & Acute rejections (two infusions) & $3 / 32(8.0 \%)^{\ddagger}$ & $16 / 100(15.0 \%)^{\ddagger}$ \\
\hline & Infections & $16 / 40(40 \%)^{\S}$ & $5 / 100(5.0 \%)^{\S}$ \\
\hline & Kidney loss (other than death) & $0 / 40(0.0 \%) *$ & $1 / 100(1.0 \%)^{*}$ \\
\hline & Mean steroid dosage at $6 \mathrm{mo}(\mathrm{mg} / \mathrm{kg})$ & $0.10 \pm 0.01(n=27)^{\|}$ & $0.14 \pm 0.01(n=51)$ \\
\hline
\end{tabular}

Table I. Variables Affecting the Outcome of the First Cadaver Renal Transplant Procedure

${ }^{*} P=\mathrm{NS} ;{ }^{*} P=0.056 ;{ }^{\S} P=0.01 ; \| P=0.09$. 


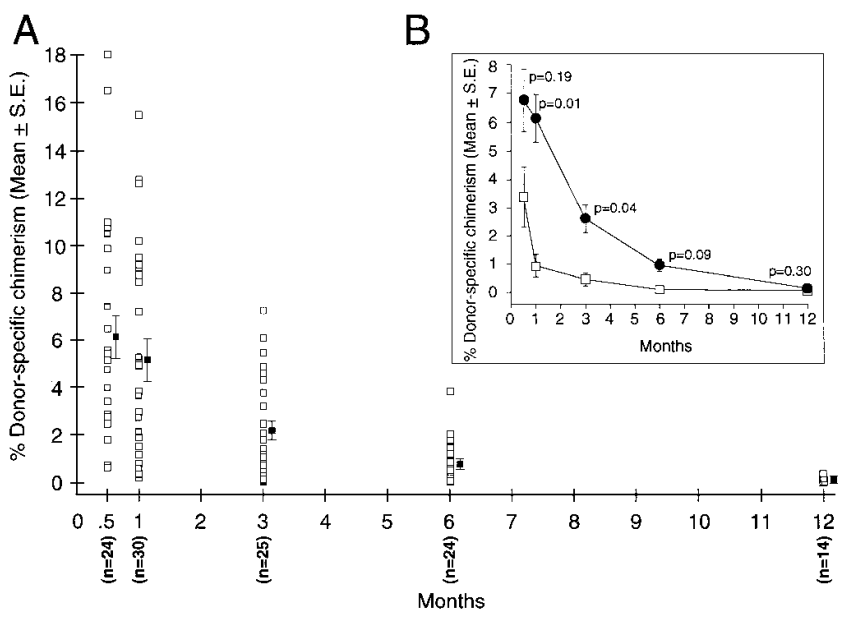

Figure 1. (A) Total chimerism of donor cell lineage tested by PCRflow analysis of ficoll-hypaque gradient samples of recipient peripheral blood mononuclear cells. (ם) Mean \pm SE. Assays were performed at $0.5,1,3$, and 6 mo and $1 \mathrm{yr}$ postoperatively. $(B)$ Comparison of chimerism in patients who experienced biopsy-proven rejection episodes $(\square)$ versus those who did not $(\bullet)$. Vertical axes in both $A$ and $B$ denote the percent chimerism found if the total number of donor cells were counted per million cells sampled in recipient peripheral blood.

II MHC (DR) antigen compatibility match between donor and recipient.

One year follow-up of peripheral blood chimerism by PCR-flow assays: factors correlating with early acute rejection episodes in the DBMC group

Chimerism analysis in DRß1 mismatched donor-recipient pairs. At present, 22 of the $40 \mathrm{DBMC}$ recipients have been followed for longer than $1 \mathrm{yr}$. These same recipients have been reported on at 6 mo (4). 14 of these 22 patients were 1DR $\beta 1$ antigen mismatched with their respective donors and could be followed by the PCR-flow assay, i.e., had reached the $1 \mathrm{yr}$ point at the time of this report ( 9 of the original 40 DBMC-infused patients were HLA DR identical with their donors). Fig. $1 A$ indicates the degree of chimerism using PCR-flow quantitation. Although there were a few recipients $(n=5)$ who had high chimerism at 6 mo and a marked decrease of DBMC in peripheral blood by $1 \mathrm{yr}$, in most patients, a trend toward stability occurred since the last report with respect to total donor cells counted and donor CD3+ and CD34+ subsets seen in peripheral blood $(n=14)$. This could be analyzed more closely in Table II in which is depicted the percent of total DBMC cells as well as CD34+ and CD3+ cells counted at 6 mo and $1 \mathrm{yr}$ posttransplant (in one million peripheral blood mononuclear cells assayed by PCR-flow). It can be noted that there is a roughly additive effect of both of these cell types to the total number of chimeric cells so that mononuclear cells expressing other epitopes of donor origin excluding CD3 or CD34 would be deduced to be in small numbers indeed in the peripheral blood at this time such as B cells, monocytes, or NK cells. The reason for this is unclear, but may be related to the lack of greater sensitivity of the PCR-flow assay at these lower levels of chimerism, which were different when bone marrow was examined (vide infra, Table IV). Despite this low number of donor cells of these subsets in recipient peripheral blood mononuclear cell preparations, we have recently observed counts many times higher in the bone marrow aspirates simultaneously sampled between 6 and 14 mo posttransplant in the same patients (4) (vide infra). This slow disappearance of cells from the peripheral blood compartment might, therefore, merely be associated with a redistribution to other lymphoreticular compartments. In 25 controls (non-bone marrow-infused recipients), donor chimeric cells were not found in any of the peripheral blood samples (followed for up to $2 \mathrm{yr}$ ).

Table II. Donor Cell Chimerism Levels at 6 and 12 Mo Detected in Recipient Peripheral Blood Mononuclear Cells

\begin{tabular}{|c|c|c|c|c|c|c|}
\hline \multirow[b]{2}{*}{ Patient } & \multicolumn{2}{|c|}{ Total cells counted* } & \multicolumn{2}{|c|}{$\mathrm{CD} 34+^{\ddagger}$} & \multicolumn{2}{|c|}{$\mathrm{CD} 3+\frac{*}{*}$} \\
\hline & $6 \mathrm{mo}$ & $12 \mathrm{mo}$ & $6 \mathrm{mo}$ & $12 \mathrm{mo}$ & $6 \mathrm{mo}$ & $12 \mathrm{mo}$ \\
\hline A.A. & 0.11 & 0.07 & 0.04 & 0.01 & 0.08 & 0.05 \\
\hline M.B. ${ }^{\S}$ & 0.11 & 0.07 & 0.02 & 0.01 & 0.09 & 0.05 \\
\hline B.B. ${ }^{\S}$ & 0.60 & 0.09 & 0.20 & 0.03 & 0.32 & 0.04 \\
\hline D.B. ${ }^{\S}$ & 0.29 & 0.05 & 0.06 & 0.01 & 0.06 & 0.05 \\
\hline E.C. ${ }^{\S}$ & 0.20 & 0.07 & 0.02 & 0.01 & 0.18 & 0.05 \\
\hline J.E. ${ }^{\S}$ & 1.80 & 0.12 & 0.07 & 0.01 & 1.72 & 0.11 \\
\hline D.J.\| & 0.06 & 0.05 & 0.01 & 0.01 & 0.05 & 0.04 \\
\hline J.M. ${ }^{\S}$ & 0.45 & 0.21 & 0.14 & 0.07 & 0.30 & 0.12 \\
\hline M.P. ${ }^{\S}$ & 0.20 & 0.05 & 0.04 & 0.01 & 0.10 & 0.03 \\
\hline I.R..$^{\S}$ & 2.60 & 0.41 & 0.95 & 0.14 & 1.56 & 0.22 \\
\hline A.R. ${ }^{\S}$ & 1.70 & 0.11 & 0.54 & 0.04 & 1.09 & 0.06 \\
\hline A.S. & 0.84 & 0.07 & 0.15 & 0.02 & 0.69 & 0.05 \\
\hline L.S. ${ }^{\S} \|$ & 0.02 & 0.02 & 0.004 & 0.004 & 0.01 & 0.01 \\
\hline R.W..$^{\S}$ & 0.51 & 0.06 & 0.22 & 0.02 & 0.28 & 0.03 \\
\hline Mean \pm SE & $0.68 \pm 0.21$ & $0.10 \pm 0.03$ & $0.18 \pm 0.07$ & $0.03 \pm 0.01$ & $0.47 \pm 0.15$ & $0.07 \pm 0.01$ \\
\hline
\end{tabular}

$*$ Percent of total donor cells/million recipient peripheral blood mononuclear cells counted in PCR-flow \pm SE. ${ }^{\ddagger}$ Percent of donor CD34+ or CD3+ subset/million recipient peripheral blood mononuclear cells counted in PCR-flow \pm SE. ${ }^{\S}$ These patients were reported on incompletely in the previous study (4), and at different time-points postoperatively. "Patients who experienced biopsy-confirmed acute rejection episodes within 4 wk after transplantation. Others are depicted in Fib. 1 B, but did not complete the full 12 mo of follow-up. 
7 of these (40) patients sustained biopsy-proven rejection episodes (one per patient) between 2 wk (0.5 mo, Fig. 1$)$ and 1 mo postoperatively. These were reversed by temporary increased immunosuppression with no further clinical evidence of rejection. These patients could be segregated from the entire group with statistically significantly lower levels of total, as well as CD3+ and CD34+ donor cell chimerism (the latter subsets not shown) per million recipient cells counted at 1 and 3 mo postoperatively (Fig. $1 B, P=0.01$ and 0.04 , respectively), and showed a trend to this segregation at 6 mo $(P=$ .09). This, in retrospect even might have begun to occur before rejection was clinically noted $(0.5 \mathrm{mo}, P=0.19)$. By 6 mo and 1 yr postoperatively, however, this group could not be statistically distinguished from the 24 and 14 patients, respectively, who did not experience detectable rejection (Fig. 1). This had also been noted in our previous report with fewer samples (4). Renal function reflected this stability with no deterioration from the improvement seen after antirejection therapy was concluded (by 1 mo after transplantation, not shown).

Chimerism analysis using class I primers when donor and recipient were class II (DR $\beta 1)$ identical. Several patients, also described in a previous report (4), received kidney transplants and DBMC infusions from DR $\beta 1$ (class II) identical donors who differed serologically at several class I HLA A and B locus disparities. Of the $40 \mathrm{DBMC}$ patients, there were 9 who received such HLA DR identical, but class I (A or B locus) mismatched kidneys. Thus far, there have been no rejection episodes in this group while 7 of the 31 patients with 1 DR donor-recipient mismatch underwent rejection episodes, perhaps indicating a trend toward a salutary effect of (DR) histocompatibility matching in DBMC infused recipients $(P=0.17)$. A few primers have since been designed to specifically identify these donor class I genes (class II DR $\beta 1$ identity); although close sequence homology of many of the class I loci causing cross-annealing of primers has hindered the routine development of class I mismatch chimerism analysis using PCR-flow assays. Since there were no clinical (or biopsy-proven) rejections detected in this HLA DR identical group, it was questioned whether chimerism quantitation might be of a greater magnitude at equivalent time points after transplantation in these patients compared to the group in which donor-recipient class II mismatches occurred. Recipients of three of these class II identical but class I mismatched donor-recipient pairs were now able to be tested because of defined class I donor-recipi-

Table III. PCR-flow Analysis of Three Patients with Donor-recipient Class II (DRß1) Identity Followed for 8 and 11, 14 and 17, and 20 and 23 Mo, Respectively, Compared at Similar Time Intervals to the Patients That Had One Class II Antigen Donor-recipient Mismatch*

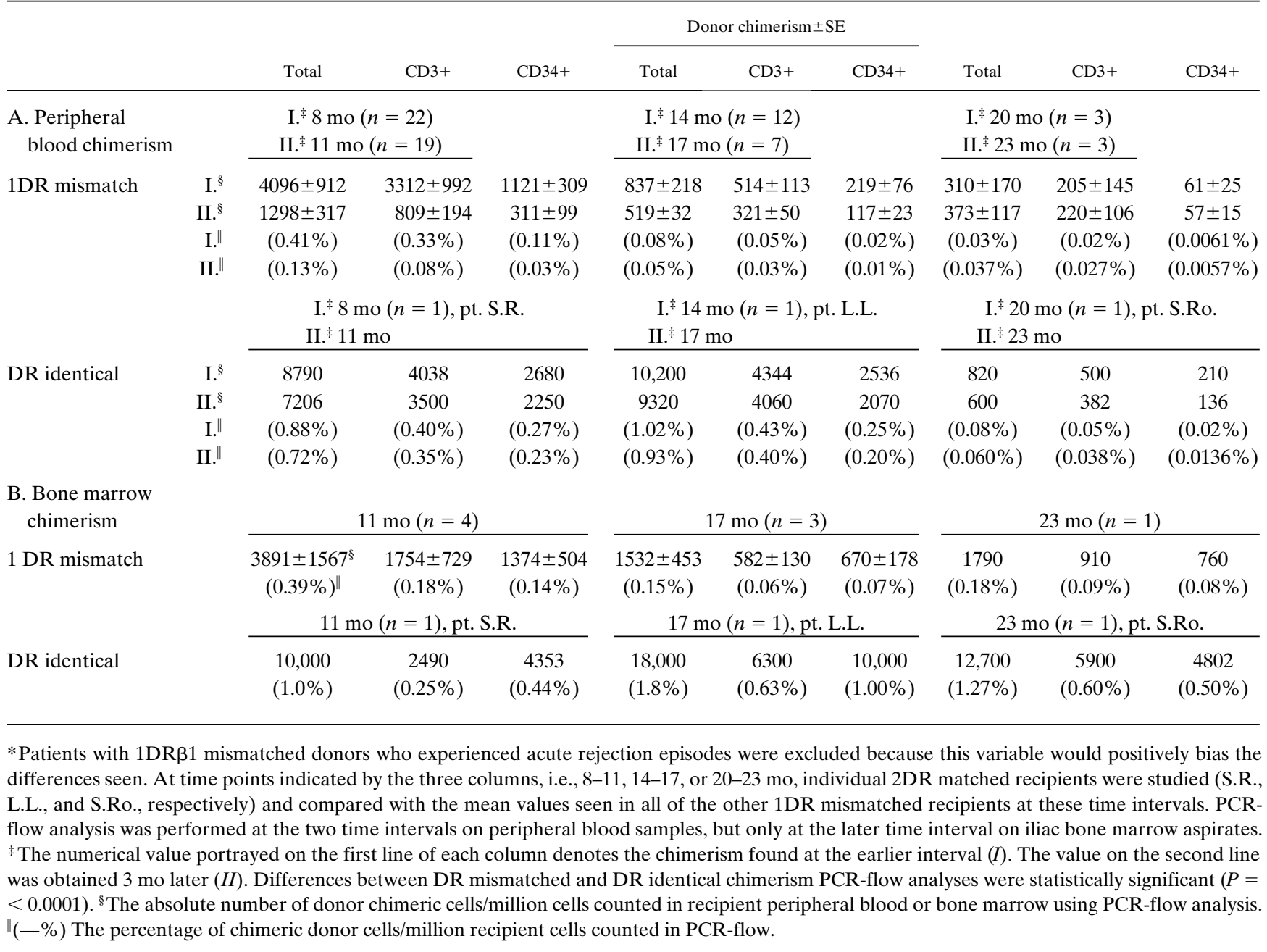




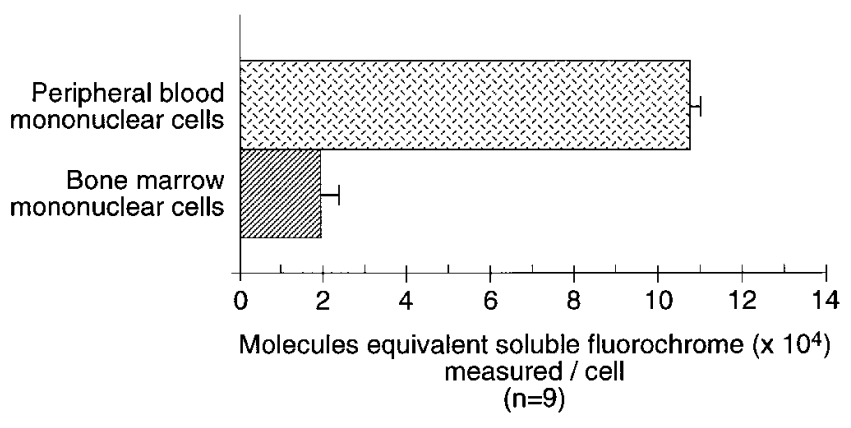

Figure 2. The differential expression of CD3 molecules by MESF analysis of $\mathrm{T}$ cells $(\mathrm{CD} 3+, \mathrm{TCR} \alpha \beta+)$ in donor peripheral blood compared with simultaneously obtained samples of donor bone marrow.

ent primer differences recently available to us. Samples tested at two time intervals in each patient were compared with the remaining (class II mismatched) DBMC recipients tested at the same time intervals. In the latter group those who experienced acute rejection and had lower levels of chimerism (Fig. 1 $B$ ), were excluded in order to remove any bias. Table III $A$ illustrates that at similar time points postoperatively, i.e., at 8 and 11 mo for patient S.R., 14 and 17 mo for patient L.L., and 20 and 23 mo for patient S.Ro., respectively, the number of donor $\mathrm{CD} 3+$ and $\mathrm{CD} 34+$ subsets in the peripheral blood of these recipients was between 2 and 10 times as frequent as those of the mean values seen in the DR mismatched group at similar intervals $(P=<0.0001$, mixed model analysis of variance). The differences appeared equally, if not even more, clear-cut when iliac crest bone marrow aspirates were compared between the DR identical and nonidentical groups (Table III $B, P=0.087$, Savage one-way analysis of variance). However, the low sample number (three patients) precluded strict statistical validation. These differences might be considered to have even more significance since two of the three (S.R. and S.Ro.) were only infused with half the number of DBMC cells in the peritransplant period, i.e., one infusion only, since not enough cells were available for the usual two infusions. In the previous report, this was clearly associated with lower eventual chimerism levels in peripheral blood (one versus two bone marrow infusions in the 1DR mismatched donorrecipient pairs) (4). In the bone marrows, both in the 1 or 2
DR matched groups, the sum of CD34+ and CD3+ cells in ficoll-hypaque preparations (similar to the peripheral blood, Table II) did not add up to the total cell chimerism. That is, cells expressing CD epitopes exclusive of CD3 and CD34 were present to be detectable in enough of a fraction for future studies on this fraction to be performed.

\section{CD3 dim TCR $\alpha \beta+C D 4-, C D 8-$ cells}

Recently "atypical" or "intermediate" T cells that are CD3 $\operatorname{dim}, \mathrm{TCR} \alpha \beta+, \mathrm{CD} 4-, \mathrm{CD} 8-$, or CD4+, and NK1.1+, which have been thought to have a more "primitive" functional activity $(13,14)$, have been described, primarily in mice. It has been reported that this cell type may not be subjected to the normal ("maturation/selection") process entailing migration through the thymus (15). Such a cell has been detected in sites of extramedullary and medullary (myeloid) formation such as the liver and bone marrow $(14,15)$. Both immune amplifying and regulatory functions have been ascribed to these cells when studied in the context of allogeneic bone marrow engraftment. As a first estimate of the influence of this cell population in the present DBMC clinical trial, nine cadaver donor marrow cell preparations were studied in multicolor fluorochrome flow cytometry before infusion, together with cadaveric peripheral blood of the same donors concomitantly obtained. Of the total number of ficoll-hypaque purified cadaver PBMC, 65.12 \pm $1.7 \%$ were of the CD3 bright, $\alpha \beta+, \mathrm{CD} 4+$, or CD8+ variety. By contrast, there were $13.5 \pm 2.3 \%$ CD3 bright cells counted in the same cadaver bone marrow preparations. There were very few CD3 dim CD4-CD8- cells in the peripheral blood $(0.78 \pm 0.2 \%)$ contrasted with approximately eight times this number $(6.43 \pm 2.9 \%)$ of CD3 dim CD4-CD8- cells counted in the bone marrow preparations. This could be more clearly established using the MESF bead quantitative multicolor analysis (16), i.e., the DBMC (T) cells actually expressed $80 \%$ fewer CD3 molecules than expressed on peripheral blood $\mathrm{T}$ cell surface membranes (Fig. 2).

In sequential studies postoperatively (retrospective, see Methods), the CD3+ dim cells of donor lineage in recipient peripheral blood on average consisted of $2.59 \pm 0.5 \%$ of the donor $\mathrm{CD} 3+\mathrm{T}$ cell population at 0.5 mo postoperatively which decreased to $0.80 \pm 0.07 \%$ by $1 \mathrm{yr}$ (Table IV). By contrast, at all times this was significantly higher than the range of CD3 dim cells $(0.44 \pm .07 \%$ to $0.29 \pm 0.05 \%)$ seen in the recipient peripheral blood $\mathrm{T}$ cell population during the same period $(P=$

Table IV. Percentage of Donor and Recipient CD3 Dim and Bright Cells in Peripheral Blood and Iliac Crest Bone Marrow Aspirates

\begin{tabular}{|c|c|c|c|c|c|c|}
\hline & $\begin{array}{c}\text { Time after } \\
\text { transplantation }\end{array}$ & $\begin{array}{l}\text { No. of patients } \\
\text { tested }\end{array}$ & $\begin{array}{c}\text { Percent of } \\
\text { donor CD3+ } \\
\text { dim cells } \pm \text { SE* }\end{array}$ & $\begin{array}{c}\text { Percent of } \\
\text { donor CD3+ } \\
\text { bright cells } \pm \mathrm{SE}^{*}\end{array}$ & $\begin{array}{c}\text { Percent of } \\
\text { recipient } \mathrm{CD} 3+ \\
\text { dim cells } \pm \mathrm{SE}^{*}\end{array}$ & $\begin{array}{c}\text { Percent of } \\
\text { recipient } \mathrm{CD} 3+ \\
\text { bright cells } \pm \mathrm{SE}^{*}\end{array}$ \\
\hline \multirow[t]{5}{*}{ Peripheral blood } & $0.5 \mathrm{mo}$ & 21 & $2.59 \pm 0.5^{\ddagger}$ & $97.41 \pm 0.5$ & $0.44 \pm 0.07^{\ddagger}$ & $99.56 \pm 0.07$ \\
\hline & $1 \mathrm{mo}$ & 26 & $1.74 \pm 0.3^{\ddagger}$ & $98.26 \pm 0.3$ & $0.35 \pm 0.04^{\ddagger}$ & $99.65 \pm 0.04$ \\
\hline & $3 \mathrm{mo}$ & 24 & $1.33 \pm 0.18^{\ddagger}$ & $98.67 \pm 0.18$ & $0.39 \pm 0.05^{\ddagger}$ & $99.61 \pm 0.05$ \\
\hline & $6 \mathrm{mo}$ & 23 & $1.00 \pm 0.13^{\ddagger}$ & $99.10 \pm 0.13$ & $0.30 \pm 0.06^{\ddagger}$ & $99.70 \pm 0.06$ \\
\hline & $1 \mathrm{yr}$ & 15 & $0.80 \pm 0.07^{\ddagger}$ & $99.20 \pm 0.07$ & $0.29 \pm 0.05^{\ddagger}$ & $99.71 \pm 0.05$ \\
\hline Bone marrow & $1 \mathrm{yr}$ & 15 & $3.99 \pm 0.6^{\S}$ & $96.01 \pm 0.6$ & $0.27 \pm 0.06^{\S}$ & $99.73 \pm 0.06$ \\
\hline
\end{tabular}

* Percent of the total CD3+ staining population (mean \pm SE); ${ }^{*}$ Statistically significantly different between donor versus recipient $\mathrm{CD} 3+$ dim cells at each time point; $P=<0.0006$; ${ }^{\S}$ Statistically significantly different between donor versus recipient $\mathrm{CD} 3+$ dim cells in recipient bone marrow in aspirates obtained one year postoperatively; $P=<0.0001$. 

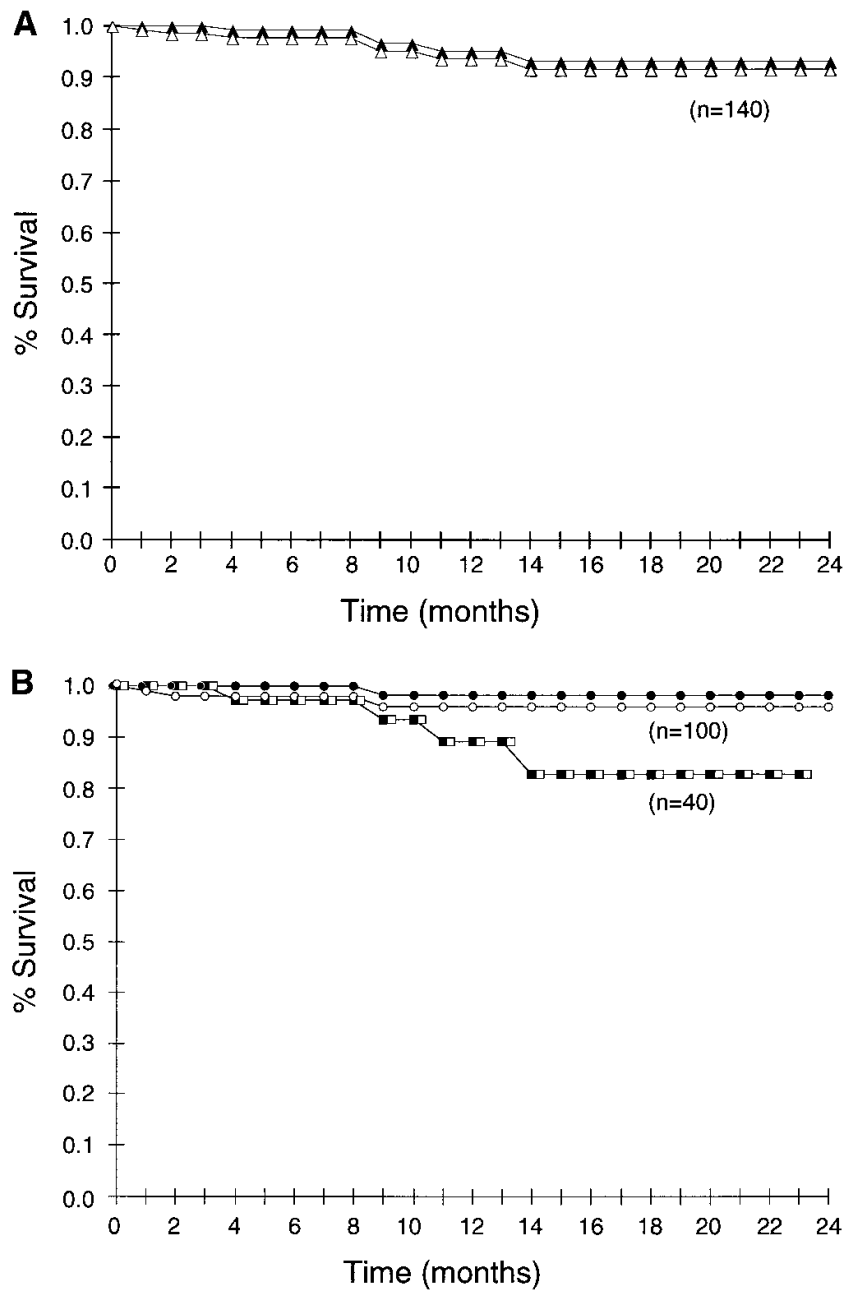

Figure 3. (A) Actuarial 24 mo patient $(\mathbf{\Delta})$ and graft $(\triangle)$ survival of the 140 patients (DBMC-infused and controls) combined. (B) Actuarial patient (Control, $\mathbf{0}$; DMBC-infused, $\mathbf{\square})$ and graft (Control, $\bigcirc$; DBMC-infused, $\square$ ) survival of each group separately ( $n=40$ and $n=$ 100 , respectively). Note that in the DBMC-infused group, graft and patient survival was equal (no graft losses occurred because of rejection; see also Table I).

$<0.0006)$. At $1 \mathrm{yr}$ postoperatively, donor CD3 dim cells were also fivefold higher in the recipient iliac crest bone marrow aspirates than in the peripheral blood (Table IV), i.e., 3.99 \pm 0.6 versus $0.80 \pm .07(P=<0.0001)$. Moreover, the donor CD3 dim subset was found to have concentrations $\sim 10$-fold higher than the recipient CD3 dim subset in the recipient bone marrow aspirates, as yet an inexplicable finding. The fact that the percentages of donor and/or recipient CD3 dim cells in the recipient iliac crest marrow were lower than might be expected from the values seen in the cadaver vertebral marrow assays (CD3 dim cells being 50\% of the number of CD3 bright cells in the marrow of the cadaver donors) is probably due, in part, to the large contamination of recipient iliac crest marrow aspirates with peripheral blood in each sample. This would result in an underestimation of the actual percentages of this subset present in the bone marrow of the recipient. However, even accounting for hemodilution, recipient CD3 dim cells were significantly proportionately even lower than the percentages to be expected from the values obtained in the cadaver donor vertebral marrow, and were equal to that seen in recipient peripheral blood $(0.27 \pm 0.06 \% \approx 0.29 \pm 0.05 \%)$. The difference of course between the two patient populations might also reflect the effects of $1 \mathrm{yr}$ of immunosuppressive therapy on the bone marrow of the recipients versus marrow obtained from (previously healthy) cadaveric brain-dead donors. At the least, the observations are again consistent with the notion of engraftment of DBMC during these periods.

\section{Clinical outcome}

The 24 mo actuarial patient and graft survival data are depicted in Fig. 3, $A$ and $B$, respectively. Overall in both the experimental and control groups combined, there were gratifying patient and graft survival results of 94.3 and $93.6 \%$, respectively, indicative of the effects of improved immunosuppressive protocols now being used in many centers (Fig. $3 A$ ). There appeared to be a trend towards a different clinical course, however, between the two groups. There were four deaths in the 40 DBMC patients which also accounted for all of the graft losses in this group (Fig. 3 B), i.e., the 24 mo actuarial patient and graft survival in the DBMC group were identical $(85.9 \%)$, with no graft loss because of rejection. In contrast, there were 2 deaths in 100 patients of the control group, with a patient and graft survival rate of 98.0 and $97.0 \%$, respectively (see also Table I $B$ ). The number of patients experiencing rejection episodes, however, appeared slightly (but not statistically) more frequent in the control group (16/100), if only the patients with two infusions in the DBMC group were considered, i.e., $3 / 32$ versus $16 / 100$. If all of the patients were considered, i.e., 7/40, there did not appear to be differences in rejection between the DBMC and control groups. By contrast, there also appeared to be a statistically increased susceptibility to morbidly significant (requiring hospitalization) viral, fungal, and bacterial infections in the DBMC group (16/40), than in the controls $(5 / 100)$ as depicted in Table I $B(P=0.01)$.

The degree of susceptibility to a state of reduced resistance was retrospectively analyzed to verify if there were any difference in steroid requirements between the two groups. Patients who had become markedly obese (weight increase $<20 \mathrm{~kg}$ postoperatively) were not included. These were proportionately equal in both groups (none of these obese patients were in the infection group). Also excluded were patients over $60 \mathrm{yr}$ of age, who were intentionally placed on a lower dosage schedule, unrelated to infection, because of poor individual tolerance. With these exclusions, 27 patients in the DBMC group were compared with 51 controls at 6 mo postoperatively. The mean methylprednisolone dosage of the patients in the DBMC group as depicted in Table I $B$ was $0.10 \pm 0.01 \mathrm{SE} \mathrm{mg} / \mathrm{kg}$ compared with $0.14 \pm 0.01 \mathrm{SE} \mathrm{mg} / \mathrm{kg}$ in the control group $(P=$ 0.09). The inherent variability of choosing a particular dosage per patient did not lend itself to deeper analyses. It was, therefore, questioned whether more objective measurements of immune reactivity might depict differences between the DBMC and control groups.

\section{In vitro correlations}

Several cellular immune mechanisms might be altered were there a possible decreased susceptibility to rejection as well as a significantly increased incidence of systemic infection in the DBMC group. Two peripheral blood in vitro lymphocyte function assays were, therefore, analyzed. 


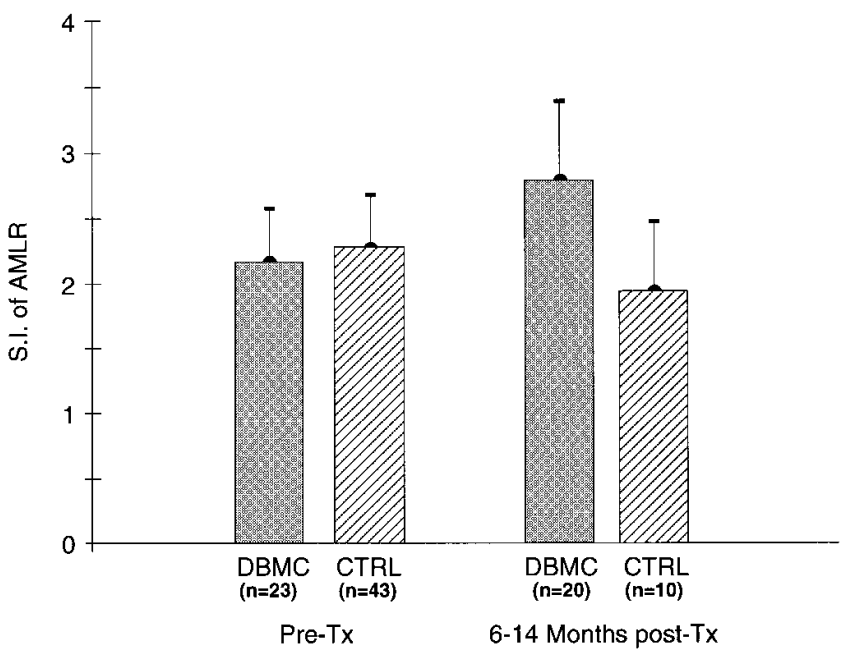

Figure 4. Autologous mixed lymphocyte reactions performed either preoperatively or 6-14 mo postoperatively in samples obtained from 23 and 10 patients, respectively, in the DBMC-infused group and 43 and 20 recipients, respectively, in the control group. Samples from other patients were not available for analysis. Note the trend towards greater activation in the DBMC-infused group.

$A M L R$. In previous reports, we have depicted the autologous mixed lymphocyte reaction, an in vitro proliferative response of purified T cells versus autologous NT cells (i.e., purified B cells and antigen presenting cells), as a screening assay of immune autoregulation, altered because of viral infections (11) or other events indicative of aberrant $\mathrm{T}$ cell reactivity against self-MHC class II molecules (or their nominal peptides) presented by antigen presenting cells (12). Thus far, the changes seen in the AMLR assays occurring between 6 and 14 mo posttransplant when compared with those obtained pretransplant have indicated a trend towards an increase in response in the DBMC group compared with preoperative reactivity (Fig. 4), and compared with the (expected) decrease in the AMLR observed in the control group as a result of the general antiproliferative effect of immunosuppressive therapy (11). In each case, the $\left[{ }^{3} \mathrm{H}\right]$ thymidine uptake of the $\mathrm{T}$ versus NT (x-irradiated) combinations yielded values of $>1,000$ CPM and the stimulation indices were each $>2$, except for the stimulation indices seen in the noninfused group postoperatively. These changes, however, were not statistically different from each other.

$M L C$. As part of the ongoing study, serial mixed lymphocyte reactions are being sequentially performed to compare modulation in donor specific or nonspecific reactivity between the pre- and posttransplant periods. Three categories of reactivity have evolved thus far between 6 and 14 mo posttransplant (in patients in which pretransplant MLC reactions have been vigorous), as also described by Zeevi et al. in a similar DBMC infusion study being performed in Pittsburgh (17). First, a decrease in both donor-specific and nonspecific MLC reactivity (nonspecific generalized immune depression or low, low reactivity). Second, specific modulation of donor-directed reactivity with nonspecific MLC reactivity remaining high (low, high reactivity). Third, reactivity to both donor and nonspecific indifferent stimulating cells remaining high (generalized retained immune responsiveness or high, high reactivity). In each of these assays in all three categories, baseline autolo-
Table V. MLC Reactivity 6-14 Mo Postoperatively of DBMC-infused Versus Control Cadaver Kidney Transplant Recipients

\begin{tabular}{lccr}
\hline \multirow{2}{*}{ Responding cells } & \multicolumn{3}{c}{ Reactivity to } \\
\cline { 2 - 4 } DBMC-infused recipients & Donor cells & Indifferent cells \\
& Low* & Low & $5 / 24$ \\
& Low & High & $15 / 24$ \\
& High & High & $4 / 24$ \\
Controls & Low & Low & $1 / 23$ \\
& Low & High & $14 / 23$ \\
& High & High & $8 / 23$ \\
& & & \\
\hline
\end{tabular}

* All low reactors demonstrated a S.I. of $<3$. All autologous (self versus $\mathrm{x}$-irradiated self) combinations demonstrated triplicate mean $\left[{ }^{3} \mathrm{H}\right]$ thymidine uptake $<1,000 \mathrm{CPM} ;{ }^{*}$ All high reactors demonstrated a S.I. of $>6$.

gous reactivity was $<1,000 \mathrm{CPM}\left[{ }^{3} \mathrm{H}\right]$ thymidine uptake means of triplicate samples. A SI of $<3 \times$ baseline was considered a low degree of reactivity with $\left[{ }^{3} \mathrm{H}\right]$ thymidine uptake of means of triplicate samples of recipient responding versus donor stimulating cells of no greater than 3,000 CPM while high SI's were considered high if the $\left[{ }^{3} \mathrm{H}\right]$ thymidine uptake was no less than 6,000 CPM, i.e., SI's of at least $6 \times$ baseline. As can be seen from Table $\mathrm{V}$, a trend toward nonspecific generalized immune depression appeared to occur in more patients in the DBMC group, i.e., 5/24 tested as low, low versus 1/23 tested as low, low in the control group, but without showing statistical significance between the groups in an isolated statistical analysis. Donor-specific immune modulation (low, high reactivity) as demonstrated by this assay appeared in more than one-half of the patients in either group during this time interval, i.e., 15 of 24 tested in the DBMC group versus 14 of 23 tested in the control group. In some contrast with this, more than twice as many recipients in the control group retained equally strong MLC reactivity against both donor and indifferent stimulating cells than in the DBMC group, i.e., 8/23 versus 4/24 were high, high reactors, respectively, also without reaching a statistically significant difference if this category were assessed in isolation. However, by combining the low, low and high, high reactor groups, mean scan statistics could be calculated to examine the location shifts of the means among both the low, low and the high, high groups using the Martel-Haenszel Chi-square test. The difference between the two groups with this test almost reached statistical significance $(P=0.053)$. Despite a range of time of 6-14 mo postoperatively when these assays were studied, they were "paired" with respect to time intervals, i.e., samples were obtained within an average of 2 wk of each other (i.e., between individuals of both groups). In addition in all the assays, PHA was used as a nonspecific mitogen ( $3 \mathrm{~d}$ response). There did not appear to be as marked a PHA response difference between the groups, although some difference was noted, i.e., the DBMC group averaged $3 \mathrm{~d}$ counts of $\left[{ }^{3} \mathrm{H}\right]$ thymidine uptake approximately one-third lower than did the controls, with much greater variability $(P=1.0)$.

\section{Differences in humoral anti-CMV immunity between the $D B M C$ and control groups}

A semi-quantitative measurement of IgG antibody to CMV by an ELISA assay was then used to assess whether humoral im- 
Table VI. Pre- and Posttransplant Measurement of Anti-CMV IgG Antibody Activity

\begin{tabular}{lccc}
\hline & $\begin{array}{c}\text { Pre-operative } \\
\text { anti-CMV IgG } \\
\text { concentration } \\
\text { in ELISA units }\end{array}$ & $\begin{array}{c}\text { Anti-CMV concentration } \\
\text { 4-6 mo postoperatively } \\
\text { in ELISA units }\end{array}$ & $\begin{array}{c}\text { Mean } \\
\text { change }\end{array}$ \\
\hline $\begin{array}{c}\text { DBMC group } \\
(n=17)^{*}\end{array}$ & $468.5 \pm 41.5$ & $504.2 \pm 36.9$ & $35.6 \pm 29.9^{\ddagger}$ \\
$\begin{array}{c}\text { Non-infused controls } \\
(n=42)^{*}\end{array}$ & $458.7 \pm 29.6$ & $552.5 \pm 29.4$ & $93.2 \pm 18.3^{\ddagger}$ \\
& & &
\end{tabular}

* Only patients with CMV-negative sera pre-operatively were excluded. Some sera could not be tested (unavailable). All values are expressed as arithmetic means \pm S.E.; ${ }^{\ddagger}$ Statistically significant $(P=<0.05)$; see text.

munity might have been affected by DBMC infusion. Sera from 17 of the 40 DBMC recipients in whom a positive antiCMV antibody by a qualitative ELISA assay was noted preoperatively were tested both preoperatively (immediately before surgery) and again between 4 to 6 mo postoperatively when immunosuppressive dosaging had reached low maintenance stability (see steroid dosage, vide supra). The concentration (ELISA intensity) of anti-CMV IgG was measured at each interval and compared with sera of 42 controls (non-DBMC infused recipients) with the same positive CMV status preoperatively. In the remaining individuals sera either were not available or there was an absence of anti-CMV antibody preoperatively (CMV-negative). There was an approximately threefold mean increase in ELISA reactivity between these two intervals in the controls as contrasted with the DBMC group (Table VI). Analysis of Variance and Duncan's Multiple Range Test were performed using PROC GLM of SAS to compare the mean difference between DBMC and control groups. Incorporated into the model were effects of DBMC or control groups and change in ELISA values. This indicated a significant difference between the two groups $(P<0.05)$. This finding might even be considered to have more impact since, as described above, the steroid dosaging showed a trend towards higher levels in the control group, with no differences between the groups in the dosage of the other immunosuppressive agents (not shown).

\section{Discussion}

The rationale of instituting a cadaver donor bone marrow infusion protocol in association with first cadaver solid organ (kidney) transplantation at this center is based upon the findings of Starzl et al. of the detection of donor cells of bone marrow lineages persisting in a "microchimeric state" in peripheral blood, lymphoid organs, and even skin many years after transplantation, and in the absence of maintenance immunosuppression (18-20). This stimulated renewed interest in the seminal work initiated by Billingham et al. in rodents (21), which, as yet, has not resulted in therapeutic protocols to induce specific immunological tolerance to human allografts of vascularized organs. The term chimerism was used $(22,23)$ following the observations by Owen (24) in the Freemartin calf dizygotic twin describing a mixture of blood cells because of cross-circulation in the common placenta in utero, and the introduction by Owen, and then Billingham et al. and Anderson et al., of this descrip- tive concept into transplantation biology. In the setting of tolerance induced in the fetal (or newborn) mouse (21), chimerism has always been synonymous with a state of permanent and lifelong specific unresponsiveness to donor tissue alloantigens, i.e., chimerism equaled tolerance, with the caveat of the intrusive presence of graft versus host disease (25). However, with the development of other experimental transplant models predominantly in rodents (26-28), it became evident that several mechanisms of inducing unresponsiveness to alloantigens could be used without the necessity for extensive and dominant donor bone marrow lineage chimerism (although "microchimerism" may have been present as a result of such cells migrating out of the graft) (29). This has given rise to vigorous controversy as to whether the presence of microchimerism is a cause or an effect of donor alloantigen specific unresponsive states $(30,31)$.

We wanted to test the hypothesis that augmenting the natural migration of such bone marrow cell lineages from the graft by large infusions of donor bone marrow cells would facilitate the development of additional chimerism of these bone marrow cell lineages earlier and more extensively, as suggested by Starzl et al. (18-20), with the clear-cut proviso that such chimerism is a necessary prerequisite of tolerance. Several additional in vitro observations from both this and other laboratories have suggested that one or more subsets of human bone marrow lineage cells would facilitate such a state of tolerance (32-34). It therefore seemed important to devise a reproducible cytological method to specifically identify and sequentially monitor for these possible subsets of donor chimeric cells in suspensions taken from several body immune compartments, such as peripheral blood, bone marrow, and even peripheral lymph nodes. The PCR-flow assay, combining the sensitivity of DNA amplification techniques with the detection of $\mathrm{CD}$ epitopes using monoclonal antibody flow cytometry analysis has now allowed for the detection of several specific cell lineages of donor origin in the recipient. It has the potential of eventually identifying the presence of such "facilitating cells" $(35,36)$ and equating this with immunological unresponsiveness. The in vitro assays described in this report, however, have demonstrated nonspecific rather than donor specific immune inhibitory effects of the donor marrow, i.e., possibly because of nonspecific effects of "suppressor cell" subsets $(33,37$, 38). In this connection, we have also previously described an in vitro bone marrow "suppressor cell" assay that is nonspecific, with the additional requirement of cell to cell contact (39).

With regard to the PCR-flow assay, several observations in this report require comment. First, it is apparent that quantitatively at least three of these donor bone marrow cell lineages $(\mathrm{CD} 3+, \mathrm{CD} 34+$, and CD3+ dim cells) slowly stabilize in peripheral blood at low levels $(<1 \%)$ by 1 yr postoperatively. What is sequentially occurring in other compartments in the recipient, such as the bone marrow or other lymphoid tissue, remains to be disclosed. We previously described a 10-fold mean increase in two of these lineages (CD3+ and CD34+) in recipient iliac crest marrow using the PCR-flow assay in a single sampling in 10 patients between 6 and 14 mo postoperatively, when compared to simultaneously sampled peripheral blood (4). The CD3 dim donor cell subset is now similarly quantifiable (vide infra). With the continued slow decline of chimerism in peripheral blood as depicted in Fig. 1, a cogent future observation would be a second PCR-flow analysis from the bone marrow in these same patients simultaneously com- 
pared with PBL to determine whether or not "engraftment" was increasing or decreasing in (at least) the bone marrow compartment as it decreased in the peripheral blood.

The second related observation was that PCR-flow analyses at, or immediately after, rejection episodes showed a significant negative effect of these early (reversible) immune events on chimerism. Again, such low peripheral blood PCR-flow measurements at $1 \mathrm{yr}$ even in the patients who previously experienced acute rejection episodes might still be associated with higher numbers of these CD3+ and CD34+ subsets in the recipient marrow at a later time, despite the early negative effect in peripheral blood.

A third observation was the correlation of significantly greater degree of chimerism in three recipients that were class II MHC DR-identical with their respective donors (Table III, $A$ and $B$ ). Of interest, was the absence of acute rejection in this group of recipients $(n=9)$. This again pointed to a quantitative correlation of increased chimerism with class II compatibility and with the absence of alloimmune reactivity. This observation supports previous ones of better kidney graft survival in humans when donor and recipients were matched for class II MHC antigens $(5,6)$, and of a greater ease of inducing allograft tolerance between pigs and in rodent inbred strains with class II MHC identity but mismatched for class I alloantigens $(40,41)$.

Finally, the presence of the CD3 dim donor T cell subset in both peripheral blood and bone marrow of the recipients up to $1 \mathrm{yr}$ postoperatively in surprisingly high levels (Table IV), just as with the donor CD34+ subset, points to engraftment having occurred, since this subset most probably originated in the donor marrow preoperatively (Fig. 2), although other less likely explanations are possible.

Although only indirectly related to PCR-flow analysis as yet, the main finding of the present report is the previously undescribed observation of an apparent generalized immunodepressed state of these DBMC recipients compared with the noninfused controls given an equivalent immunosuppressive therapeutic regimen. The first indication of this was the increased incidence of infection requiring hospitalization (Table I $B$ ), as well as a possibly related trend toward a reduced steroid dosaging requirement (the latter, admittedly, subjective). These data were obtained somewhat earlier than the MLC reactions, which spanned a longer period postoperatively (6-14 mo). It was, however, also supported by in vitro T cell-mediated cellular, as well as humoral immune assays. Three patterns of response were seen in MLC reactions performed between 6 and 14 mo after transplantation as depicted in Table V. (In each case, MLC reactivity preoperatively was strong versus the specific donor as well as a panel of indifferent cell donors.) The first pattern was a general inhibition of alloreactivity, i.e., decreased lymphoproliferation against the specific donor, as well as versus a panel of indifferent cell donors (low, low reactivity). The incidence of this low, low pattern appeared to favor the bone marrow-infused patients. The second pattern was a specific immunomodulation of MLC reactivity versus donor cells, but with a continuing strong reaction versus the indifferent panel (low, high reactivity). This specific adaptation to the allograft appeared to be just as frequent in the controls as in the marrow-infused recipients between 8 and 14 mo posttransplant. This was also described by Zeevi et al. (17) and Reinsmoen et al. (42). The third pattern was a retention of a strong lymphoproliferative response both against the donor and the indifferent cell panels, i.e., the absence of either specific immunomodulation or of generalized immunodepression. The pattern appeared to favor the controls by eight to four. Although DBMC and control groups did not appear to differ in the first and third categories if examined as isolated observations, when looked at in combination, statistical significance $(P=0.058)$ was almost reached, indicating a trend towards less responsiveness in the $\mathrm{DBMC}$ group.

Although also just indicative of a trend, the differences seen in the auto-MLR activity between the two groups may have had one of the following alternative explanations. First, indicative of altered responses to nominal peptides presented by autologous antigen presenting cells in the DBMC group as we have previously described in hepatitis $C$ virus-infected recipients (12), in the present case possibly cytomegalovirus (despite depressed humoral immunity), which also appeared to be more clinically detectable in the bone marrow-infused group (not shown). Second, indicative of a small number of donor chimeric cells in recipient peripheral blood stimulating the recipient $\mathrm{T}$ cells by either direct or indirect alloantigen presentation. Because of the few peripheral blood cells of donor origin seen in PCR-flow at this time $(<2 \%)$, we do not favor this latter possibility.

The negative impact of DBMC on recipient humoral immunity to CMV was more definitive, as seen by the anti-CMV ELISA test results. Using this semiquantitative antibody assay as an indicator of humoral resistance, the first finding was that there was an increase in the 4-6 mo postoperative responses compared with preoperative responses seen in both groups (i.e., in which a lower level of anti-CMV IgG antibody positivity was present preoperatively). This might have been as a result of an additional exposure to CMV, i.e., a later increase in antibody response because of viral reactivation occurring in the first few weeks postoperatively because of early heavy immunosuppression characterized by OKT3 induction in both groups. However, the bone marrow-infused group did not respond as strongly to this putative re-exposure and had lower levels of antibody by 4-6 mo postoperatively. Several interpretations are feasible. First, we have previously reported on immune modulation involving antigenic mimicry, i.e., crossreacting antiidiotypic responses between CMV and T cell membrane epitopes, the common connection being an immunosuppressed condition brought about by OKT3 in certain patients (43-45). Such a network aided by regulatory cells in the infused marrow might be operational in the DBMC group as a possible explanation for the altered CMV antibody activity. Second, although we did not observe graft versus host reactivity, were a subclinical grade to be operative, this might be another explanation for the decreased resistance to infection and depressed cellular and humoral immunity (46). Third, MHC restrictive mechanisms might have been affected in the immune compartments, where chimerism could have been even more prominent than in the marrow, such as lymph nodes or spleen (purely speculative since PCR-flow observations were not made in any lymphoid organ as of yet, other than bone marrow). Allogeneic APC's would be deficient in presenting nominal peptides (virus or other) to host $\mathrm{T}$ cells and vice versa in recipients with significant chimerism of these respective subsets. Finally, the detection of CD3 dim cells of donor bone marrow lineage persisting long-term in these recipients might connote T cells of an "intermediate type" to which regulatory functions have been ascribed recently (13-15), which could 
also affect T cell-mediated humoral (B cell) anti-CMV immunity. Unfortunately, differences in IgM antibodies were not assessed, which might have correlated with reactivation of an acute CMV infection. Other causes of increased infection because of the bone marrow infusions could not be found, such as (a) each marrow was routinely cultured for bacteria and fungi at procurement and found to be negative before infusion; (b) when cytomegaloviral disease or other opportunistic infections occurred in the bone marrow-infused group, this appeared, in recipients who were CMV positive pre-transplant and in whom the donors were either CMV positive or negative; or (c) antibody status versus Epstein-Barr virus did not appear to play a role in either the donor or recipients, i.e., all had IgG (convalescent) antibody at the time of transplantation. However, no attempt was made to perform PCR analysis or to culture viruses from the marrow specimens.

This report appears to raise more questions than it answers with respect to the effects of bone marrow infusions to augment renal transplant acceptance, and on the effects of chimerism on tolerance, especially with the new findings of an immunodepressed state evoked by bone marrow infusions, compared with a similarly treated group of controls. It might be questioned as to why such an observation of decreased immunity has not been observed yet in other series of liver or kidney transplant recipients augmented by donor bone marrow at this center $(7,8)$ or in recent reports from the University of Pittsburgh $(2,47)$ or earlier from the University of Alabama by Barber et al. (1). Perhaps the simplest explanation is that the immunosuppressive therapeutic regimen of the series reported here has been the strongest to date of the bone marrow-infusion protocols in transplant recipients, consisting of OKT3 antibody induction and maintenance tacrolimus and methylprednisolone, as well as, more recently, of mycophenolate mofetil. The addition of bone marrow infusions to this strong baseline immunosuppressive regimen might have been enough to uncover this underlying mechanism. Indeed, there have been many instances in clinical transplantation in which an overly suppressed state brought about by immunosuppressive therapy and then followed by viral illness, etc., has been associated with successful long-term (months to years) total withdrawal of immunosuppressive drugs. In patients such as these, donor cell chimerism analysis by PCR-flow technology in specific compartments of the immune system might elicit the presence of functionally important donor bone marrow lineage subsets in the future.

\section{Acknowledgments}

The authors wish to express their gratitude for the expert desktop publishing efforts of Wynn Howard and for the technological expertise of Carmen Gomez, Teresa Vallone, and Sharon Babischkin.

This work was supported by Miami Veterans Administration Hospital Research Support, National Institutes of Health grants R01DK25243-15 and R01DK50759, and Fujisawa USA.

\section{References}

1. Barber, H.W., J.A. Mankin, D.A. Laskow, M.H. Deierhoi, B.A. Julian, J.J. Curtis, and A.G. Diethelm. 1991. Long-term results of a controlled prospective study with transfusion of donor-specific bone marrow in 57 cadaveric renal allograft recipients. Transplantation (Baltimore). 51:70-75.

2. Fontes, P., A. Rao, A.J. Demetris, A. Zeevi, M. Trucco, P. Carroll, W. Rybka, C. Ricordi, F. Dodson, R. Shapiro, et al. 1994. Augmentation with bone marrow of donor migration for kidney, liver, heart, and pancreas islet transplantation. Lancet (N. Em. Ed.). 344:151-155.

3. Ricordi, C., T. Karatzas, J. Nery, M. Webb, G. Selvaggi, L. Fernandez, R. Garcia, M. Goldberg, E. Schiff, L. Olson, et al. 1997. High-dose human donor bone marrow infusions to enhance allograft survival. Transplant. Proc. In press.

4. Garcia-Morales, R., V. Esquenazi, K. Zucker, C.I. Gomez, L. Fuller, M. Carreno, R. Cirocco, A. Alamo, T. Karatzas, G.W. Burke III, et al. 1996. An assessment of the effects of cadaver donor bone marrow on kidney allograft recipient blood cell chimerism by a novel technique combining PCR and flow cytometry. Transplantation (Baltimore). 62:1-12.

5. Morris, P.J., and A. Ting. 1982. Studies of HLA-DR with relevance to renal transplantation. Immunol. Rev. 66:103-111.

6. Ayoub, G., and P. Terasaki. 1982. HLA-DR matching in multicenter, single-typing laboratory data. Transplantation (Baltimore). 33:515-517.

7. Ricordi, C., T. Karatzas, G. Selvaggi, J. Nery, M. Webb, H. Fernandez, P. Ruiz, S.-S. Kong, J. Miller, E. Schiff, and A. Tzakis. 1995. Multiple bone marrow infusions to enhance acceptance of allografts from the same donor. Ann. N.Y. Acad. Sci. 770:345-351.

8. Ricordi, C., T. Karatzas, G. Selvaggi, J. Nery, H. Fernandez, M. Ruiz, E. Linetsky, S.-S. Kong, M. Webb, R. Bottino, et al. 1995. Enhanced allograft acceptance by multiple infusions of donor bone marrow in humans. Transplant. Proc. 27:3381.

9. Poncelet, P., and P. Corayou. 1985. Cytofluorometric quantitation of cell surface antigens by indirect immunofluorescence using monoclonal antibodies. J. Immunol. Methods. 85:65-74.

10. Fuller, L., G. Kyriakides, C. Flaa, V. Esquenazi, and J. Miller. 1980. In vitro generation of human mixed lymphocyte culture suppressor cells. I. Cellular characterization and specificity. Transplantation (Baltimore). 29:54-60.

11. Fuller, L., C. Flaa, D. Jaffe, J. Strauss, G.K. Kyriakides, and J. Miller. 1983. Factors affecting the autologous mixed lymphocyte reaction in kidney transplantation, autoimmune states and normal human subjects. I. Cellular. $J$. Clin. Invest. 71:1322-1330.

12. Zucker, K., D. Roth, R. Cirocco, J. Mathew, M. Carreno, L. Fuller, T. Karatzas, Y. Jin, G. Burke, J. Nery, et al. 1996. Transplant-associated autoimmune mechanisms in human hepatitis $\mathrm{C}$ virus infection. J. Clin. Immunol. 16: 60-70.

13. MacDonald, R.H. 1995. NK1.1+ T cell receptor- $\alpha \beta+$ cells: new clues to their origin, specificity, and function. J. Exp. Med. 182:633-638.

14. Vicari, A.P., and Z. Zlotnik. 1996. Mouse NK1.1+ T cells: a new family of T cells. Immunol. Today. 17:71-76.

15. Kikly, K., and G. Dennert. 1992. Evidence for extra-thymic development of $\mathrm{T}_{\mathrm{NK}}$ cells: NK1 $+\mathrm{CD} 3+$ cells responsible for acute marrow graft rejection are present in thymus-deficient mice. J. Immunol. 149:403-412.

16. Carreno, M., C. Gomez, R. Gharagozloo, R. Cirocco, K. Zucker, R. Garcia, L. Fuller, V. Esquenazi, A. Tzakis, and J. Miller. 1997. Assessment of homozygosity in HLA-class I antigens and their distribution/quantitation in subpopulations of cells by flow cytometry. Transplant. Proc. In press.

17. Zeevi, A., M. Pavlick, S. Lombardozzi, R. Banas, O. Pappo, A. Rao, P. Fontes, J. Demetris, R. Shapiro, F. Dodson, et al. 1995. Immune status of recipients following bone marrow augmented solid organ transplantation. Transplantation (Baltimore). 59:616-620.

18. Starzl, T.E., A.J. Demetris, M. Trucco, N. Murase, C. Ricordi, S. Ilstadt, H. Ramos, S. Todo, A. Tzakis, J.J. Fung, et al. 1993. Cell migration and chimerism after whole organ transplantation: the basis of graft acceptance. Hepatology. 17:1127-1152.

19. Starzl, T.E., A.J. Demetris, M. Trucco, A. Zeevi, H. Ramos, P. Terasaki, W.A. Rudert, M. Kocova, C. Ricordi, A. Ilstadt, and N. Murase. 1993. Chimerism and donor specific nonreactivity 27 to 29 years after kidney allotransplantation. Transplantation (Baltimore). 55:1272-1277.

20. Starzl, T.E., A.J. Demetris, N. Murase, A.W. Thomson, M. Trucco, and C. Ricordi. 1993. Donor cell chimerism permitted by immunosuppressive drugs: a probable basis of organ transplant acceptance and tolerance. Immunol. Today. 14:326-332.

21. Billingham, R.E., L. Brent, and P.B. Medawar. 1952. "Actively acquired tolerance" of foreign cells. Nature (Lond.). 172:603-604.

22. Billingham, R.E., G.H. Lampkin, P.B. Medawar, and H.L. Williams. 1952. Tolerance to homografts, twin diagnosis, and the freemartin condition in cattle. Heredity. 6:201-221.

23. Anderson, D., R.E. Billingham, G.H. Lampkin, and P.B. Medawar. 1951. The use of skin grafting to distinguish between monozygotic and dizygotic twins in cattle. Heredity. 5:379-397.

24. Owen, R.D. 1945. Immunogenetic consequences of vascular anastomoses between bovine twins. Science (Wash. DC). 102:400-401.

25. Billingham, R., and L. Brent. 1956. Quantitative studies on transplant immunity. IV. Induction of tolerance in newborn studies on the phenomenon of runt disease. Philos. Trans. R. Soc. Lond. B. Biol. Sci. 242:439-477.

26. Lafferty, K.J., A. Bootes, G. Dart, and D.W. Talmage. 1976. Effect of organ culture on the survival of thyroid allografts in mice. Transplantation (Baltimore). 22:138-149.

27. Bluestone, J.A., O. Leo, S.L. Epstein, and D.H. Sachs. 1986. Idiotypic manipulation of the immune response to transplantation antigens. Immunol. Rev. 90:5-27. 
28. French, M.E., and J.R. Batchelor. 1972. Enhancement of renal allografts in rats and man. Transplant Rev. 13:115-141.

29. Larsen, C.P., P.J. Morris, and J.M. Austyn. 1989. Migration of dendritic leukocytes from cardiac allografts into host spleen. J. Exp. Med. 171:307-314.

30. Shirwan, H., H.K. Wang, L. Barwari, L. Makowka, and D.V. Cramer. 1996. Pretransplant injection of allograft recipient with donor blood or lymphocytes permits allograft tolerance without the persistent donor microchimerism. Transplantation (Baltimore). 61:1382-1386.

31. Hisanaga, M., J. Handriese, K. Boker, K. Uthoff, G. Raft, T. Wahlers, K. Wonigeit, R. Pichlmayr, and H.J. Schild. 1996. Development, stability, and clinical correlations of allogeneic microchimerism after solid organ transplantation. Transplantation (Baltimore). 61:40-45.

32. Ciancio, G., M. Carreno, J. Mathew, C. Ricordi, R. Garcia, T. Karatzas, L. Fuller, R. Cirocco, J. Nery, M. Webb, et al. 1996. Human donor bone marrow cells can enhance hyporeactivity in renal transplantation using maintenance FK506 and OKT3 induction therapy. Transplant. Proc. 28:943.

33. Palathumpat, V., S. Dejbakhsh-Jones, B. Holm, H. Wang., O. Liang, and S. Strober. 1992. Studies of CD4-CD $-\alpha \beta$ bone marrow T cells with suppressor activity. J. Immunol. 148:373-380.

34. Thomas, J.M., K.M. Verbanae, and F.T. Thomas. 1991. The veto mechanism in transplant tolerance. Transplant. Rev. 5:209-213.

35. Thomas, J.M., F.M. Carver, P.R. Cunningham, L.C. Olson, and F.T. Thomas. 1991. Kidney allograft tolerance in primates without chronic immunosuppression - the role of veto cells. Transplantation (Baltimore). 51:198-207.

36. Thomas, J.M., F.M. Carver, J. Kasten-Jolly, C.E. Haisch, L.M. Rebellato, U. Gross, S.J. Vore, and F.T. Thomas. 1994. Further studies of veto activity in rhesus monkey bone marrow in relation to allograft tolerance and chimerism. Transplantation (Baltimore). 57:101-115.

37. Muraoka, S., and R.G. Miller. 1980. Cells in bone marrow and in T cell colonies grown from bone marrow can suppress generation of cytotoxic $\mathrm{T}$ lymphocytes directed against their self antigens. J. Exp. Med. 252:54-71.

38. Sugiura, K., S. Ikehara, M. Inaba, S. Haraguchi, H. Ogata, E.E. Sardiña, M. Sugawara, Y. Ohta, and R.A. Good. 1992. Enrichment of murine bone marrow natural suppressor activity in the fraction of hematopoietic progenitors with interleukin 3 receptor-associated antigen. Exp. Hematol. (Charlottesv.). 20: 256-263.

39. Mathew, J., M. Carreno, L. Fuller, C. Ricordi, T. Karatzas, A. Tzakis, V. Esquenazi, and J. Miller. 1995. Modulatory effect of bone marrow cells on immune responses. Hum. Immunol. 44(Suppl. 1):34 \#4.2.

40. Pescovitz, M.D., J.R. Thistlethwaite, Jr., H. Auchincloss, Jr., S.T. Ilstadt T.G. Sharp, R. Terrill, and D.H. Sachs. 1984. Effect of class II antigen matching of renal allograft survival in miniature swine. J. Exp. Med. 160:1495-1508.

41. Cobbold, S.P., G. Martin, S. Qin, and H. Waldmann. 1986. Monoclonal antibodies to promote marrow engraftment and tissue tolerance. Nature (Lond.). 373:164-166.

42. Reinsmoen, N.L., C. McSherry, A.J. Jackson, M.I. Hertz, R.M. Bolman, and A.J. Matas. 1995. Circulating donor antigen and response to donor antigen as predictors of long-term lung and kidney transplant success. Transplant. Proc. 27(1):205-206.

43. Carreno, M., W.-C. Yang, V. Esquenazi, L. Fuller, G. Burke, M. Milgrom, D. Roth, D. Ranjan, and J. Miller. 1990. OKT3 induction (via idiotypic networks) of mirror image immunosuppressive anti-immunoglobulins in renal transplant recipients. Transplantation (Baltimore). 49:408-415.

44. Carreno, M., L. Fuller, K. Zucker, W.-C. Yang, G. Burke, J. Nery, C. Gomez, V. Esquenazi, and J. Miller. 1992. Cross species reactivity of the antiidiotype anti-OKT3 cascade between mouse and man. Hum. Immunol. 33:249_ 258.

45. Yang, W.-C., M. Carreno, V. Esquenazi, L. Fuller, D. Ranjan, G. Burke, D. Roth, and J. Miller. 1991. Evidence that antibodies to cytomegalovirus and the $\mathrm{T}$ cell receptor (TCR)/CD3 complex may have common ligands. Transplantation (Baltimore). 51:490-498.

46. Blaese, M.R., C. Martinez, and R.A. Good. 1964. Immunologic incompetence of immunologically runted animals. J. Exp. Med. 119:211-224.

47. Rao, A.S., P. Fontes, A. Zeevi, M. Trucco, F.S. Dodson, W.B. Rybka, R. Shapiro, M. Jordan, S.M. Pham, H.L. Rilo, et al. 1995. Augmentation of chimerism in whole organ recipients by simultaneous infusion of donor bone marrow cells. Transplant. Proc. 27:210-212. 